\title{
Principals' Instructional Supervisory Role Performance and Teachers' Motivation in Ekiti Central Senatorial District of Ekiti State, Nigeria
}

\author{
Dr. Babatope Kolade Oyewole \\ Department of Educational Foundations \& Management, \\ Faculty of Education, Ekiti State University, Ado-Ekiti, Nigeria \\ E-mail-oyewole.tope@yahoo.com

\section{Dr. Hezekiah Ogbomida Alonge} \\ Department of Educational Studies \& Management \\ Faculty of Education, University of Benin, Benin City, Nigeria \\ E-mail:Alohezek@yahoo.com
}

\section{Doi:10.5901/jesr.2013.v3n2p295}

\begin{abstract}
This research article investigates principals' instructional supervisory role performance and teachers' motivation in Ekiti Central Senatorial District of Ekiti State, Nigeria. The population of the study consisted of all the principals and teachers of public secondary schools in Ekiti Central Senatorial District of Ekiti State, Nigeria. The researchers utilized two sets of research instruments titled Instructional Supervisory Role Performance (ISRP) and Teachers' Motivation Questionnaire (TMQ) which were responded to by teachers. Data analyses indicated a significant relationship between instructional supervisory role performance of principals and the motivation of their teachers. A significant positive relationship was found between experience of principals in performing their instructional supervisory roles and the motivation of their teachers. There was also a significant relationship between instructional supervisory role performance of principals of large schools and small smalls and the motivation of their teachers. Based on the findings, it was concluded that principals should pay more attention to their instructional supervisory role performance as it has a significant influence on the motivation of their staff while Ekiti State Ministry of Education in collaboration with the state Teaching Service Commission should organise periodically seminars, conferences and workshops for school principals to enable them handle instructional supervisory role more effectively while the welfare of teachers should be adequately improved.
\end{abstract}

Keywords : Instructional supervision, motivation, performance, principals, experience, secondary school, teachers.

\section{Introduction}

The importance of instructional supervisory role performance of secondary school principals in today's educational system cannot be overemphasized. There has been a consensus view that a lot of differences exist between the schools of the past and those of the present especially in EkitiState which is well known as 'Fountain of Knowledge' among other states in Nigeria. In a way, this has been attributed to the explosion of students' population in schools and the level of commitment by the teachers. Consequently, the present school system is unable to cope with the increasing welfare responsibilities of both staff (teachers) and students.

Management expects employees to be motivated towards increased production, the same is also applicable to the school system. Principals are expected to motivate the teachers under them for the effective achievement of educational goals and objectives. Today, moral decadence and other social vices have become very prevalent in the school system. All these shortcomings have been blamed on the school principals. Parents expect the school to provide solution to these problems as the school is considered to be an agent of change within Nigerian society, and of course all over the world. The only way therefore to achieve this change is through principals' supervisory role performance and well-motivated teachers. 
In the very past, instructional supervisory role of principals was little because schools were small in size (Ezedi, 1995, Shantz and Ward, 2000). With increased demand for education and consequent large enrolment of students particularly in the urban areas, secondary schools grew to have many teachers and many classrooms. The need then arose for someone to coordinate the activities of the school by supervising the other teachers in an effort to improve educational instruction.

In EkitiState, secondary schools were divided into junior and senior sections before, with each school having a principal for effective supervision of instruction. This was the practice for over ten years. In September, 2011, the Junior Secondary Schools (JSS) and Senior Secondary Schools (SSS) were merged together as a single school to be supervised by a principal with the assistance of two or three vice principals depending on school size. With these new arrangements, some principals were made vice-principals. Hence a formidable team was therefore developed to administer the school system. However, every focus is now on the principal level of competency to manage the existing situation with high morale on the part of the teachers. He is recognized as the most important functionary in the school. He is the administrative head, the manager, supervisor, as well as instructional leader, a curriculum innovator and a catalyst towards planned educational revolution (Thobega $\&$ Miller, 2002).

Motivation in school hinges on how satisfied or dissatisfied teachers are, with their jobs. Kyte (2001) observed that the idea and willingness of organizational members to work together towards the achievement of organizational goals is an essential characteristic of organization in general. It is only through highly motivated faculty that educational organization can facilitate student learning in certain directions since the instructional supervisory role system interacts with teaching behaviour system, it is assumed therefore, that one outcome of the interaction would be the enhancement of motivation of teachers through the instructional supervisory role performance of school principals.

\section{Concept of Instructional Supervision}

Supervision of instruction is one of the several techniques employed in achieving educational objectives, Nwaogu (1980) defined supervision of instruction as a process or an activity by which an individual or a group or team of individuals, by means of advising and stimulating interest in teachers, pupils, help to improve teaching and learning situations in educational institutions. According to Harris (!995), supervision is directed towards both maintaining and improving the teaching learning process of the school. In the words of Rettig (2000), supervision is an organised behaviour system, which has the function of interacting with the teaching behaviour system for the purpose of improving the learning situation of children.

Adewumi (2000) remarked that behaviour of supervisor is assumed to be related to the improvement of teachers' performance. In Nigeria, there has been a critical analysis on what instructional supervision should be. Omoregie (2002) saw instructional supervision as an internal process (micro-inspection). He opines that microinspection concerns itself with regular resources utilization and processes in a school and the maintenance of lines of action that promote productivity. The principal as the school administrator should, therefore, perform the within-school supervisory role in instructional improvement and in evaluation of education. School principal should therefore, assist teachers in determining the right methods, teaching facilities, physical settings, classroom attributes that are most likely to promote effective learning in schools.

\section{The Concept of Motivation}

Human motivation is a complex phenomenon. Management expects employees (teachers) to be motivated towards increased production by providing incentives. Berelson (1964) defines motivation as inner state that energizes, activate a person and direct his behaviours towards goals. Beach (1975) defines it as the willingness to expend energy to achieve a goal or reward. In providing a more descriptive definition of motivation, Robbins(1982) asserts that the term motivation is the willingness to do something and it is conditioned by those action and ability to satisfy some needs for the individual.

An unsatisfied need creates tension which stimulates desire within the individual. These drives generate a search behaviour to find particular goals that if attained, satisfy the need and lead to the reduction of tension. Unmotivated employees are in a state of tension. In order to relieve this tension, they engage in activity. The 
greater the tension, the greater the activity to bring about relief. Therefore, when we see people working hard at some activities, we can conclude that they are driven by a desire to achieve some goals that they perceive as having value to them. It can therefore be concluded based on this theory, that the unmotivated teachers in the school system fights tool and nail to get out of the system. If teachers are well motivated, the teachers will be happy and put in more efforts on their jobs, and better results will be achieved through the students.

\section{Principals' Supervisory role and teachers' motivation}

The principal in a school system is a professional leader. He is the foremost supervisor who combines the roles of administration supervisor, instructional supervisor and subject supervisor. Spears (1993) asserts that, of all the school personnel, the principal is in the best position to receive the overall public reaction to the school effort. The principal therefore is seen as one who combines all efforts in the school system towards the realization of set objectives and this can be achieved through the cooperation and support of his teachers. Consequently, the teachers have to be motivated to be in the right frame of mind to deliver qualitative instruction to the students.

One of the problems confronting school today is that of motivating teachers to perform assigned tasks to meet predetermined standards. Steiner (2002) opines that, it is not easy to motivate an individual, for the success of any motivational effort depends on the extent to which the motivator meets the needs of the individual employees for whom it is intended.

Motivation is related to leadership, for good leadership sets an example, provides guidance, encouragement and instruction and these can be the greatest motivation to the system. Schools with effective leadership (principals) have motivated staff (teachers) and students. Motivation of teachers is highly related to morale. High morale is difficult to attain in the school system; motivation is a prime factor, in achieving it through the headship of the school.

In research findings of related studies on supervision and motivation, Akubue (1981) observed that principals' poor instructional supervisory role performance was found because they were incompetent and preoccupied with other demanding routine functions. Boardman (1993) discovered that in schools enrolling approximately 500 pupils, the principals tended to spend the major part of their time in the duties of their offices. In large schools, they rarely taught, spending most of the time on administration. The research also revealed that though the amount of experience was related to the size of the school, there had been slow but steady increase in experience. Akpan (2001) observed that in schools, where the principals were able to reconcile the needs and aspirations of the teachers with the needs of the school, students tended to achieve better academic performance than in those schools where the principals did not show enough concern for both the welfare of the teachers and the need of the schools.

Based on the findings from other studies and problems of the study, the following research questions are raised to direct this study.

1. Is there any relationship between principals' instructional supervisory role performance and teachers' motivation in Ekiti Central Senatorial District of Ekiti State.?

2. Is there any relationship between instructional supervisory role performance of experienced principals and the motivation of their teachers in Ekiti Central Senatorial District of EkitiState?

3. Is there any relationship between instructional supervisory role performance of inexperienced principals and the motivation of their teachers in Ekiti Central Senatorial District of EkitiState

4. Is there any relationship between instructional supervisory role performance of principals in large schools and the motivation of their teachers in Ekiti Central Senatorial District of EkitiState?

5. Is there any relationship between instructional supervisory role performance of principals in small schools and the motivation of their teachers in Ekiti Central Senatorial District of EkitiState?

\section{Hypotheses}

Based on the above research questions, the following hypotheses are generated.

$\mathrm{Ho}_{1}$ : There is no significant relationship between instructional supervisory role performance of principal and the motivation of their teachers in Ekiti Central Senatorial District of EkitiState. 
$\mathrm{Ho}_{2}$ :There is no significant relationship between the instructional supervisory role performance of experienced principals and the motivation of their teachers.

$\mathrm{Ho}_{3}$ :There is no significant relationship between the instructional supervisory role performance of inexperienced principals and the motivation of their teachers.

$\mathrm{Ho}_{4}$ :There is no significant relationship between the instructional supervisory role performance of principals of large schools and the motivation of their teachers.

$\mathrm{Ho}_{5}$ :There is no significant relationship between the instructional supervisory role performance of principals of small schools and the motivation of their teachers.

\section{Methodology}

The descriptive survey research design was used to carry out this study. The research was designed to elicit information with which to determine the relationship between principals' instructional supervisory role performance and their teachers motivation in Ekiti Central Senatorial District of Ekiti State, Nigeria. The study was also to determine whether factors like experience of principals and size of school influence the relationship between principals instructional supervisory role performance and teachers motivation. Thus, appropriate suggestions could be made towards improving education in the study area.

The population of this study consisted of principals and teachers in all the public secondary schools in Ekiti Central Senatorial District of Ekiti State, Nigeria. At the time of this study, there were fifty eight (58) secondary schools in Ekiti Central Senatorial District of Ekiti State, Nigeria while the total number of teachers in this Senatorial District was two thousand one hundred and ninety two $(2,192)$. A simple random sampling technique was used to select twenty schools. This allowed for good sample representation. Ten teachers were randomly selected from each school. Therefore, the participants of this study consisted of twenty (20) principals and two hundred (200) teachers.

The researchers utilized two sets of instruments titled Instructional Supervisory Role Performance (ISRP) and Teachers Motivation Questionnaire (TMQ). These research instruments were constructed by the researchers based on findings from the review of the literature related to the study. These two sets of Questionnaires were responded to by teachers. Besides these two forms of Questionnaires, there was another meant for the principals of the sampled schools. It was a general Questionnaire to elicit information on the size of school and experience of the principals. The (ISPR) Questionnaire designed to identify Principal's Instructional Supervisory Role Performance as perceived by their teachers composed of twenty questions. The response to each question was weighted at four point Likert type scale. A response of most often had four (4) points, often had three (3) points, occasionally had two (2) points while rarely had one (1) point. The TMQ designed to identify the motivation level of teachers also consisted of twenty questions. The response to each question also was weighted at four point Likert type scoring scales of Strongly Agree (4 pints), Agree (3 points), Disagree (2 points) and Strongly Disagree (1 point).

The two instruments (ISRP and TMQ) were validated by experts and the reliability of the two instruments (ISRP and TMQ) were analysed using the Statistical Package for Social Sciences (SPSS) and the results gave a reliability coefficient of 0.85 and 0.96 respectively.

\section{Results}

Data obtained through ISRP and TMQ were analysed, and all hypotheses were tested at the 0.05 level of significance using SPSS. Since the relationship was the issue in question in the hypotheses, the Pearson Product Moment Correlation analysis was used to determine the relationship between the independent and dependent variables.

$\mathrm{Ho}_{1}$ : There is no significant relationship between principals' instructional supervisory role performance and the motivation of their teachers. 
Table 1: Summary of Pearson Product Moment Correlation analysis on Instructional Supervisory Role Performance of Principals and the motivation of their teachers

\begin{tabular}{|l|l|l|l|}
\hline Variables & N & r-cal & r-table \\
\hline Instructional Supervisory Role Performance of Principals & 200 & \multirow{3}{*}{0.195} \\
\hline Teachers' Motivation & 200 & 0.72 & \multirow{2}{*}{0.195} \\
\hline
\end{tabular}

* $\mathrm{P}<0.05$

Hypothesis 1 was rejected as there was a significant relationship between the instructional supervisory role performance of principals and the motivation of their teachers since $r$-cal of 0.72 is greater than the r-table value of 0.195 at 0.05 alpha level. Since the relationship is linear and positive, it means then, that the way and manner the principals handle their instructional supervisory role will automatically influence the motivation of their teachers positively or negatively.

$\mathrm{Ho}_{2}$ : There is no significant relationship between the instructional supervisory role performance of experienced principals and the motivation of their teachers.

Table2: Summary of Pearson Product Moment Correlation analysis of Instructional Supervisory Role Performance of experienced principals and the motivation of their teachers

\begin{tabular}{|l|l|l|l|}
\hline Variables & $\mathbf{N}$ & r-cal & r-table \\
\hline $\begin{array}{l}\text { Instructional supervisory Role Performance of } \\
\text { Experienced Principals }\end{array}$ & 110 & & \\
\cline { 1 - 2 } Teachers' Motivation & 110 & 0.74 & 0.195 \\
\hline
\end{tabular}

$* P<0.05$

Since the $r$-cal of 0.74 is greater than the $r$-table value of 0.195 at 0.05 level of significance, the null hypothesis is rejected. It is therefore concluded that there is a significant positive relationship between experience of principals in performing their instructional supervisory roles and the motivation of their teachers.

Ho3: There is no significant relationship between the instructional supervisory role performance of inexperienced principals and the motivation of their teachers.

Table 3: Summary of Pearson Product Moment Correlation analysis of Instructional Supervisory Role Performance of inexperienced principals and the motivation of their teachers

\begin{tabular}{|l|l|l|l|}
\hline Variables & N & r-cal & r-table \\
\cline { 1 - 2 } $\begin{array}{l}\text { Instructional Supervisory Role Performance } \\
\text { of Inexperienced Principals }\end{array}$ & 90 & & \\
\cline { 1 - 2 } Teachers' Motivation & 90 & 0.66 & 0.205 \\
\hline
\end{tabular}

* $\mathrm{P}<0.05$

Since the $r$-cal value of 0.66 is greater than the $r$-table value of 0.205 at 0.05 level of significance, the null hypothesis is rejected. It is therefore concluded that there is a significant positive relationship between the instructional supervisory role performance of inexperienced principals and the motivation of their teachers. However, the calculated correlation coefficient of 0.74 between the instructional supervisory role performance of experienced principals and their teachers' motivation is greater than that of inexperienced principals. This tends to suggest that experience of principals is more relevant in influencing teachers' motivation.

$\mathrm{Ho}_{4}$ : There is no significant relationship between the instructional supervisory role performance of principals of large schools and the motivation of their teachers. 
Table 4: Summary of Pearson Product Moment Correlation Analysis of Instructional Supervisory Role Performance of Principals of large schools and the motivation of their teachers

\begin{tabular}{|c|c|c|c|}
\hline Variables & $\mathbf{N}$ & r-cal & r-table \\
\hline $\begin{array}{l}\text { Instructional Supervisory Role Performance } \\
\text { of Principals in large schools }\end{array}$ & 110 & & \\
\hline Teachers' Motivation & 110 & 0.64 & 0.195 \\
\hline
\end{tabular}

Since the $r$-cal value of 0.64 is greater than $r$-table value of 0.195 at 0.05 level of significance, the null hypothesis is therefore rejected, it is hereby concluded that there is a significant relationship between the instructional supervisory role performance of principals of large schools and the motivation of their teachers. The relevance of this finding could be seen more clearly in relation to the next hypothesis.

$\mathrm{HO}_{5}$ : There is no significant relationship between the instructional supervisory role performance of principals of small schools and the motivation of their teachers.

Table 5: Summary of Pearson Product Moment Correlation Analysis of Instructional Supervisory Role Performance of Principals of small schools and the motivation of their teachers

\begin{tabular}{|c|c|c|c|}
\hline Variables & $\mathbf{N}$ & r-cal & r-table \\
\hline $\begin{array}{l}\text { Instructional Supervisory Role Performance } \\
\text { of Principals of small schools }\end{array}$ & 90 & \multirow[b]{2}{*}{0.79} & \multirow[b]{2}{*}{0.205} \\
\hline Teachers' Motivation & 90 & & \\
\hline
\end{tabular}

Since the $r$-cal value of 0.79 is greater than $r$-table value of 0.205 at 0.05 level of significance, the null hypothesis is rejected. It is therefore concluded that there is a significant positive relationship between the instructional supervisory role performance of principals of small school and the motivation of their teachers. The principals of small size schools appeared to influence the motivation of their teachers more significantly than their counterparts in large size schools.

Size of school therefore appears to be crucial in influencing teachers' motivation by principals in the performance of their instructional supervisory role.

\section{Discussions}

The findings of this study revealed that there is significant relationship between the instructional supervisory role performance of principals of secondary schools in Ekiti Central Senatorial District of Ekiti State, Nigeria and the motivation of their teachers. The relationship is linear and positive. It goes to explain that the way principals of secondary schools carry out instructional supervisory role influences the motivation of their teachers. The principals who are effective in their instructional supervisory role will bring high motivation on the part of the teachers. This is in consonance with the submission of Maslow (1970) that said" motivation is a factor which closely influences the performance of work and overall efficiency of an organization. If this principle is applied to the school system, one will observe that the instructional supervisory role as carried out by principal will either motivate teachers to put in their best to system or otherwise. This brings into focus that the instructional supervisory role performance is of paramount importance in the school system (Oyewole, 2008). To this end, the Ministry of Education should ensure concrete and concerted efforts towards making school principals pay adequate attention to instructional supervisory role.

Another finding of this study in relation to principals' experiences on instructional supervisory role performance and the motivation of their teachers revealed that there is no significant relationship between the instructional supervisory role performance of experienced and inexperienced principals on the motivation of their teachers. The relationship between the instructional supervisory role performance of experienced 
principals and teachers' motivation has a calculated coefficient value of 0.74 which is higher than the calculated coefficient value of 0.66 for the relationship between instructional supervisory role performance of inexperienced principals and teachers' motivation. Since both the scores on teachers' ratings of instructional supervisory role performance of principals on the level of motivation are low, it is believed that the instructional supervisory role performance of inexperienced principals is likely to bring about low level of motivation among teachers. Experience therefore seems to have a high positive relationship with instructional supervisory role performance of principals which in turn influenced the motivation of teachers. This is in line with Nwaeze (1995) which proved that there is a significant difference between the experienced and the inexperienced principals in the performance of their instructional supervisory duties. Harbison and Hanushek (1992) also found in their study that, teaching experience relates positively to learning. There is no doubt that instructional supervisory role performance of experienced principals is likely to motivate their teachers in a more unique way than that of inexperienced principals. In support of this assertion, Okolo (2001) opined that more experienced headmasters perform their administrative functions than the inexperienced ones. Infact, Ogunsaju (1983) succinctly put it thus "usually older staff members look at young principals as inexperienced and immature". The researchers are strongly of the view that experience should be considered as one of the major factors in the posting and appointment of principals of secondary schools in Nigeria.

The relationship between the instructional supervisory role performance of principals of large and small schools and the motivation of their teachers revealed significant positive correlation. It is pertinent to note that the calculated correlation coefficient of 0.79 for principals of small schools is greater than the calculated correlation coefficient of 0.64 for principals of large schools. It therefore suggests that, the instructional supervisory role performance of principals of small school influence the motivation of their teachers more than their counterparts in large schools. From this finding, it could be observed that the size of school is very crucial in influencing teachers' motivation. It is apparent that small schools are more amenable to instructional supervisory role performance of principals than the large schools. In the light of this, concerted efforts should be made by Ekiti State Ministry of Education for even distribution of students into public secondary schools, over populated schools should be decongested where necessary especially in the urban areas.

\section{Conclusion}

Based on the analysis of the data gathered, it was concluded that there was a significant relationship between the instructional supervisory role performance of principals and the motivation of their teachers in Ekiti Central Senatorial District of Ekiti State, Nigeria. It was also discovered that, there was a significant relationship between the instructional supervisory role of experienced principals and the motivation of their teachers. There was also a significant relationship between the instructional supervisory role performance of inexperienced principals and the motivation of their teachers. It is assumed that these findings have some implications for practice and for further research. Since experience is a very relevant factor in school administration, only well experienced principals should be appointed to handle very complex schools for optimum productivity.

There was a significant relationship between the instructional supervisory role performance of principals of large schools and the motivation of their teachers. There was also a significant relationship between the instructional supervisory role performance of principals of small schools and the motivation of their teachers. Consequent upon these findings, it could therefore be recommended that principals should pay more attention to their instructional supervisory role performance as it has a significant influence on the motivation of their staff. School supervision and inspection should be prioritized by the Ministry of Education for effective service delivery by the school principals.

The Ministry of Education in collaboration with the Teaching Service Commission in EkitiState should organize periodically seminars, conferences and workshops for school principals to enable them handle instructional supervisory role more effectively. It is pertinent to say that the Ministry of Education as the controlling agent of schools and its staff should strive to meet up with the genuine demands of teachers in order to promote good working relationship between the principals and their teachers. The recent withdrawal of $27,5 \%$ of Teachers Salary Scale (TSS) allowance being paid to professional teachers in EkitiState as approved by the Federal Government of Nigeria needs to be resuscitated. This will go a long way to improve the level of teachers' motivation in EkitiState. Principals should also establish means of getting feed-back from teachers in 
their schools in order to assess their instructional supervisory role performance more meaningfully and improve positively on their areas of strengths and weaknesses.

\section{References}

Adewumi, S. A. (2000): "The Relationship Between Supervisory Climate and Teacher - Student Performance in Secondary Schools in Oyo State" Unpublished P.hD Thesis University of Ibadan.

Akpan, E. T. (2001) The Relationship Between Principals Supervisory Leadership and Students Academic Performance in Secondary Schools in Calabar Municipality. Unpublished M.Ed Thesis University of Ibadan.

Akubue, A. U. (1981) "In-Service Needs of Secondary School Principals in Instructional Supervision: A Case Study of Anambra State of Nigeria. Ph.D Dissertation University of Nigeria, Nsukka.

Beach, D. S. (1975) Personnel: The Management of People at work Macmillan Publishing Co. Inc.

Berelson, B. (1964) Human Behaviour: An Inventory of Scientific Findings New York, Brace Inc.

Boardman, C. (1993) Democratic Supervision in Secondary Schools Massachusettes, Hereghter Mifflin Co.

Ezedi, H. G. (1995) Measuring the Effective Teacher: Problems and Prospects Journal of Teachers Education 2 (1) 18-22.

Harbson, R. W. and Hanushek, E. A. (1992) Educational Performance of the Poor; Lesson from the Ural North East Brazil; Oxford University Press.

Harris, B. M. (1995) Supervision Behaviour in Education New Jersey Englewood Cliffs Prentice Hall Inc.

Kyte, G. (2001) Job Satisfaction Among America Teachers; Effects of Workplace conditions, background Characteristic and teachers compensation Washington, Department of Education.

Maslow, H. A. (!970) Motivation and Personality 2nd ed. New York, Harper and Row.

Nwaeze, F. (1995) "An Analysis of Instructional Supervisory Performance of Secondary School Principal in Edo State, Nigeria" M.Ed Thesis University of Benin

Nwaogu, J. I. (1980) A Guide to Effective Supervision of Instruction in Nigerian Schools. Enugu: Fourth Dimension Publishing Co. Ltd.

Ogunsaju, S. (1983) Educational Supervision, Perspectives and Practices in Nigeria Ile-Ife: University of Ife Press Ltd.

Okolo, C. O. (2001) 'An Evaluation of the Performance of Primary School Headmasters M.Ed Thesis University of Benin.

Omoregie, S. B. (2002) Planning the monitoring functions of school Inspection for the School System. Seminar Paper Presented to School Inspectors Benin City.

Oyewole, B. K. (2008) Instructional Supervision and Job Performance Among Secondary School Teachers in Ekiti State, Nigeria. Unpublished Ph.D Thesis Adekunle Ajasin University Akungba-Akoko.

Rettig, P. R. (2000) "Leslie's Lament: How can I make teachers' supervision meaningful Educational Horisons 79 (1) 33 37.

Robbins, S. P. (1982) Personnel: The Management of Human Resources Englewood, Prentice Hills Inc.

Shantz, D. and Ward, T. (2000) Feedback, Conservation and Power in the field experience of preservice teachers Journal of Instructional Psychology 27 (4), 288-294.

Spears, A. (1993) Improving the Supervision of Instruction Englewood Cliffs N. J. Prentice Hall.

Steiner, A. F. (2002) "Handling non-response issues" Journal of Educational Extension 21, 45-50.

Thobega, G. S. and Miller, I. L. (2002). Supervising the Beginning Teacher Danville, I. L. The Interstate Publishers and Printers. 